\title{
OBSERVATIONS ON NEPHROPS NORVEGICUS (L.) AND ON AN EPIZOIC POPULATION OF BALANUS CRENATUS BRUG.
}

\author{
By H. Barnes and T. B. Bagenal \\ The Marine Station, Millport
}

\section{(Text-figs. I-4)}

The Dublin Prawn or Norway Lobster, Nephrops norvegicus (L.), is widely distributed on soft muddy bottoms, usually between Io and 50 fathoms. It is found as far north as Iceland and the North Cape, is common in the North Sea and off the Atlantic shores of the British Isles, and extends as far south as the coast of Morocco; a variety, v. meridionalis (Zariquiey-Cenarro, I935) is found in the Mediterranean and Adriatic (see Havinga, I929, and Heldt \& Heldt, I93I, for details of its distribution). Some aspects of the general biology of Nephrops have been dealt with by Höglund (1942) and Poulsen (1946) for Scandinavian waters, and by McIntosh (1904, I908) and Storrow (I9I2) for the waters off north-east England. To a large extent all these workers relied on market catches.

In the Clyde Area, where Nephrops is found in very considerable quantities at certain times of the year, a number of collections has been made, and information concerning the size, sex and presence of females in berry has been obtained. In addition, having repeatedly observed the presence of epizoic barnacles (Balanus crenatus Brug.) on many of the prawns, it was thought that observations on these might help, not only to interpret the prawn data, particularly with regard to the time and frequency of moulting, but in addition might give some information on the growth of barnacles under these rather unusual conditions.

\section{The Methods and Material}

The hauls were taken with a V.D. trawl (see Barnes \& Bagenal, I95I, for details) on grounds off the Island of Bute and off Knock Castle (full Kilometre National Grid References 26/II59-II62 and 26/I763-I767). The first collection (June I950) was taken from the former ground, and the later ones (July, August, October I950 and January I95I) from the latter ground at a depth of 20 fathoms, where the prawn was found to be more plentiful. Supplementary hauls were taken in these and other places and will be referred to where appropriate.

All the prawns were measured from the point of the rostrum to the telson, to the nearest half centimetre below, and the sex and presence of berried 
females noted. At the same time, the small numbers of barnacles on telson, abdomen and cephalothorax were noted. The chelipeds which bore most of the epizoic barnacles were then removed and all the barnacles measured (carino-rostral length, using an eyepiece micrometer) and their distribution on the various parts of the chelipeds, namely meropodite, carpopodite, propodite and dactylopodite together, noted. In all, some I200 Nephrops and 8000 barnacles have been examined and measured.

\section{The Growth Rate of BALANUS CRENATUS ON NEPHROPS NORVEGICUS}

In the Firth of Clyde Balanus crenatus liberates nauplii throughout most of the year except for the winter months, but the major liberation and subsequent settlement takes place in the spring followed by a moderate liberation and settlement in August (Pyefinch, I948).

Table I. The Estimated Mean Sizes (mM.) of Balanus crenatus Populations on NEPHROPS OBTAINED FROM Size-FrequenCIES AND Analyses by Cumulative Percentages: Each Size-Group of Nephrops Analysed Separately and the Range of Means Given.

\begin{tabular}{|c|c|c|c|c|c|c|c|c|}
\hline \multirow[b]{2}{*}{ Collection } & \multicolumn{2}{|c|}{ Population I } & \multicolumn{2}{|c|}{ Population II } & \multicolumn{2}{|c|}{ Population III } & \multicolumn{2}{|c|}{ Population IV } \\
\hline & $\begin{array}{l}\text { Range } \\
\text { of } \\
\text { means }\end{array}$ & $\begin{array}{l}\text { Grand } \\
\text { mean }\end{array}$ & $\begin{array}{l}\text { Range } \\
\text { of } \\
\text { means }\end{array}$ & $\begin{array}{l}\text { Grand } \\
\text { mean }\end{array}$ & $\begin{array}{l}\text { Range } \\
\text { of } \\
\text { means }\end{array}$ & $\begin{array}{c}\text { Grand } \\
\text { mean }\end{array}$ & $\begin{array}{l}\text { Range } \\
\text { of } \\
\text { means }\end{array}$ & $\begin{array}{c}\text { Grand } \\
\text { mean }\end{array}$ \\
\hline $\begin{array}{l}\text { June } 195^{\circ} \\
\text { July } 1950\end{array}$ & $\begin{array}{l}\mathrm{I} \cdot 3-\mathrm{I} \cdot 6 \\
\mathrm{I} \cdot 5-2 \cdot \mathrm{I}\end{array}$ & $\begin{array}{l}1.5 \\
I .8\end{array}$ & & & $\begin{array}{l}8 \cdot I^{\star} \\
8 \cdot 5^{\star}\end{array}$ & $\begin{array}{l}8 \cdot 1 \\
8.5\end{array}$ & 二 & $=$ \\
\hline 1950 & & $2 \cdot 5$ & $3 \cdot 4-5 \cdot 7$ & 4.9 & - & - & - & - \\
\hline Octol & $4 \cdot 2-5 \cdot I$ & 4. & & & - & - & $0.5-I .4$ & 0.7 \\
\hline January $195 \mathrm{I}$ & $4 \cdot 4^{\star}$ & $4 \cdot 4$ & - & - & - & - & $1 \cdot 8^{\star}$ & $\mathrm{I} \cdot 8$ \\
\hline
\end{tabular}

Size-frequency curves for the barnacles on each centimetre size-group of Nephrops have been drawn and analysed, and it has been found that in each collection of Nephrops similar barnacle populations were present irrespective of the size-group of the prawn (see later for exceptions and further discussion). In considering the barnacle populations all those collected on a given date are therefore considered together. The range of the estimated mean size from the various Nephrops size-groups and the estimated grand mean for these barnacle populations are shown in Table I. They are also plotted in Fig. I, from which the following construction regarding the settlement and growth of these barnacles is put forward.

During the sampling period, from June to January, four populations (I-IV) of barnacles were found. The large individuals (mean 8. I mm.) of population III were represented only in the June and July samples and then only as a very small fraction (c. 10\%) of the whole barnacle population; population IV (small individuals, mean $0.7 \mathrm{~mm}$.) was present only in the October 
and January samples and in the latter as a moderate proportion (c. $20 \%$ ) of the whole. It seems clear from Fig. I that the growth-curve of population I is that of the spring settlement I950, since extrapolation indicates its origin during the heavy April settlement. The growth-curve of population IV would seem to correspond to the moderate August settlement noted by Pyefinch (1948). The mean growth-rate in population I was uniform throughout the summer but fell off during the winter (see Pyefinch), whereas in population IV little growth took place before the winter and there was only a small increase in size between October and January. Allowing for this reduced growth rate during the winter and plotting the values as a hypothetical second

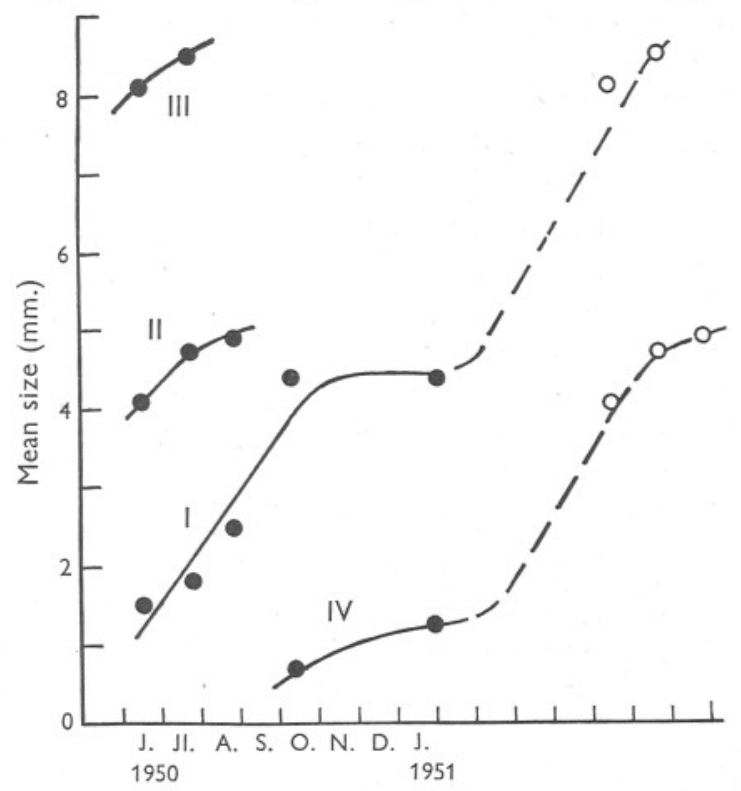

Fig. I. The mean size of the Balanus crenatus populations. I, spat of spring I950; II, spat of autumn I949; III, spat of spring I949; IV, spat of autumn I950. - - - , next year (hypothetical).

year, with 'normal' growth rate established for populations I and IV in the following spring, it seems clear that the spring population of one year gives rise to the third (III) population observed in the spring of the next year; thus the extended curve I is equivalent to two seasons' growth of a spring settlement, so that population III, observed in June and July 1950, is the spring settlement of 1949. The autumn settlement becomes the medium-sized population II (extended curve IV) during the year after settlement; it is smaller since it has had only one period of maximum growth-rate, namely during the spring of its second year. The growth-curve of population IV thus gives rise in the second year to the curve of population II. To these is added the spring settlement in the second year. 
On this hypothesis the growth-rates of the spring settlement during the summer months of its first year and also of the settlement of the previous autumn in its second year are very similar, about $2 \mathrm{~mm}$. in 4 months. This is in marked contrast with the growth-rate of Balanus crenatus on raft-exposed panels, for which Pyefinch gives up to $0.2 \mathrm{~mm}$. per day: it is more comparable with the value given by Topsent (I9II) of $5-6 \mathrm{~mm}$. in $3 \frac{1}{2}$ months for $B$. crenatus growing on the shore. Other observations have confirmed the high growth-rate on raft-exposed panels, and it would seem that the extremely slow growth-rate of the barnacles settled on Nephrops is largely due to the habitat of the prawn since, as Crisp (I95I) has pointed out, the growth-rate of barnacles varies enormously in different environments. He finds that growth is greatest in clean water and high currents, while in slow currents, and particularly in the presence of much silt, it is considerably reduced. The latter conditions are, of course, just those which appertain to barnacles epizoic on Nephrops.

The above results emphasize the necessity of caution in the use of epizoic fauna as evidence regarding the age of the 'host' (as used, for example, by Foxon, 1940). For Balanus crenatus at any rate, and probably other species, only measurements of individuals growing under comparable conditions should be used.

A feature of interest not evident from the discussion may be mentioned. The enormous settlement of $B$. crenatus in 1950 resulted in material such as stones, shells or debris from the sublittoral zone usually being completely covered with living barnacles during the late spring and early summer. By late summer, although large quantities of calcareous remains were left on such material, living barnacles were comparatively few; indeed the whole population had been decimated. In contrast, all the barnacles examined from the Nephrops were living. The barnacles on the Nephrops may have owed their survival to a 'protective' action of the prawn, or perhaps to the absence of the predators in the muddy bottom habitat of Nephrops.

\section{The Moulting of the NEPHROPS}

The population of large barnacles (III) was confined to two size-groups of Nephrops, I7-I8 and 20-2I cm., in the first two collections of June and July (populations I and II being also present), and there were four other examples of a single barnacle population on a given size-group. Apart from these exceptions all the Nephrops size-groups at any given date had the same barnacle populations (twenty-five sets in all). It should, of course, be remembered that some Nephrops of each size-group were barnacle-free at any time. This suggests that moulting usually takes place irrespective of size-group; at no time did a given Nephrops size-group lose all its epizoic barnacles, or carry a distinctive barnacle population. Now it may be seen from Fig. I that, 
on the hypothesis put forward in the previous section, the spring barnacle settlement of one year is lost by August of the next year (population III, although present in small numbers- $2 \%$ of the total-in July was absent in August) and further, the summer settlement of one year is lost by the autumn of the next year (population II, although present up to August, was absent in October). The life of a barnacle on a prawn does not exceed one year. This suggests that in any size-group a Nephrops moults at least once a year. It cannot be ascertained from these results whether any given prawn moults more frequently, but few individuals appear to moult less than once a year, at any rate not enough to contribute a detectable population of barnacles to that carried by a given size-group. It may be objected that the barnacles

\begin{tabular}{|c|c|c|c|c|c|}
\hline $\begin{array}{l}\text { Size group } \\
(\mathrm{cm} .)\end{array}$ & June & July & August & October & January \\
\hline $7-8$ & 0 & $\circ$ & 0 & 0 & - \\
\hline $8-9$ & 0 & $\circ$ & 0 & 0 & - \\
\hline $9-10$ & 0 & $\circ$ & o & o & - \\
\hline IO-II & 0 & $\circ$ & 0 & 0 & 0 \\
\hline II $-\mathrm{I} 2$ & o & o & o & 0 & - \\
\hline $12-13$ & $5 \mathrm{I}$ & 6 & I3 & 0 & - \\
\hline $13-14$ & $3 \mathrm{I}$ & Io & 9 & - & - \\
\hline $14-15$ & 50 & I3 & 19 & 57 & $\circ$ \\
\hline $15-16$ & 43 & 24 & $4 \mathrm{I}$ & 64 & 0 \\
\hline I6-I7 & 75 & 37 & 38 & 83 & (66) \\
\hline $17-18$ & 79 & 57 & 46 & $8 \mathrm{I}$ & 56 \\
\hline I8-I9 & 89 & 45 & 58 & 83 & 50 \\
\hline $19-20$ & 100 & $5 \mathrm{I}$ & 76 & 88 & 92 \\
\hline $20-21$ & 100 & 35 & $(100)^{\star}$ & 79 & 86 \\
\hline $2 I-22$ & 100 & 43 & & 100 & (I00) \\
\hline
\end{tabular}

themselves do not live after the first year; this, however, would seem unlikely, since Balanus crenatus is known to live for much longer periods in its normal habitat, and, further, had this been so, their calcareous bases would have been left and observed.

The above results indicate that some moulting takes place in the late spring and also in the early autumn. Table II gives the percentages, at each collection, of the Nephrops in the various size-groups with barnacles (for a consideration of the barnacle-free size-groups see p. 377), and the drop in these percentages between the June and July collections indicates that some moulting also took place at this time. There is little change in these percentages in August, and the increase in October is presumably due to the moderate barnacle settlement in August. The numbers of Nephrops in the January collection were small, and the values are therefore less reliable, but the decrease in the $17-19 \mathrm{~cm}$. sizegroups may be due to moulting or perhaps mortality of the smaller barnacles during the winter months. Storrow (I9I2) found that soft or 'recovering' 
males were found mainly in the spring catches (April), but some were present throughout the year except in the late autumn and early winter (SeptemberNovember).

\section{Maturity and BReeding Season of NePhrops}

In all these collections only seventy-eight female Nephrops have been taken, compared with 1200 males, and on no occasion were the females ever more than $9 \%$ of the catch (Table III): Poulsen gives the proportion of females in his material as about $30 \%$. In the Scandinavian material berried females were found in all the size-groups greater than I $2 \mathrm{~cm}$., but Havinga (I929) gives the size at sexual maturity, presumably for material in more southerly regions, as Io $\mathrm{cm}$., with rare individuals at 8 and $9 \mathrm{~cm}$. Storrow (I9I2, I9I3) records berried females at 9-II $\mathrm{cm}$. but the majority were in the size-groups greater than II cm. Most of the berried females collected in the supplementary hauls in this region were in the size-groups of $10 \mathrm{~cm}$. and above, but a small number have been found berried at $7.5 \mathrm{~cm}$.

\begin{tabular}{|c|c|c|c|c|c|}
\hline $\begin{array}{l}\text { Size group } \\
\text { (cm.) }\end{array}$ & June & July & August & October & January \\
\hline $8-9$ & 0 & I & 2 & 0 & \\
\hline 9-IO & I & 2 & 5 & 0 & \multirow{6}{*}{$\begin{array}{l}\text { Nil, but very } \\
\text { small catches }\end{array}$} \\
\hline IO-I I & 0 & IO & IO & I & \\
\hline $\mathrm{II}-\mathrm{I} 2$ & 5 & II & 6 & 2 & \\
\hline I $2-I_{3}$ & I & 8 & 3 & I & \\
\hline $\mathrm{I}_{3}-\mathrm{I} 4$ & 3 & 0 & I & I & \\
\hline I4 4 -I5 & I & I & o & 2) & \\
\hline Total & I I & 33 & 27 & 7 & 一 \\
\hline Berried & $\circ$ & 0 & 2 & 0 & 一 \\
\hline $\begin{array}{l}\text { Percentage of } \\
\text { total catch }\end{array}$ & 8.0 & $5 \cdot 6$ & $8 \cdot 8$ & $3 \cdot 4$ & - \\
\hline
\end{tabular}

Berried females have been taken from August to January, and in all these eggs were in the unripe green state. This is in agreement with Storrow's observation that spawning takes place from July to September and, according to this worker, the female carries the eggs for a long period, and then hatching takes place in the following spring and summer. It would seem that the spawning and hatching take place somewhat later than in Scandinavian waters (see Poulsen, I946).

Poulsen has suggested that the fact that the percentage of berried females sometimes approaches $50 \%$ of the adult female population indicates a biennial spawning, and that any reduction below this value is due to the berried females burrowing more deeply. There seems little evidence to support the view that the females in general burrow more deeply (see p. 377), and the very small proportion of berried females recorded here and also by Storrow would indicate a very infrequent spawning. An alternative possibility is that the females, after fertilization, tend to migrate away from the grounds usually 
fished, for Meek (I903, I9I3, I9I4) has suggested that the well-known migration of crabs is related to the ripening of ova: it seems clear from his work that female crabs migrate far more readily than males. In Meek's work the percentage of female Nephrops dropped from June-August and this would agree with fertilization in late spring and subsequent migration.

\section{The Size and Sex Ratio of NEPHROPS}

The frequency of the various size-groups is given in Tables III and IV, and for the males the appropriate histograms have been drawn in Fig. 2. The range in size both for males and females, 7-24 and 7-15 cm., respectively, is similar to that given by both Poulsen and Storrow, although the former records occasional males as large as $25 \mathrm{~cm}$., while the latter's records do not show any larger than $22 \mathrm{~cm}$. (The lower size limit is, of course, determined in part by the trawl-mesh size used).

\begin{tabular}{|c|c|c|c|c|c|}
\hline \multirow{3}{*}{$\begin{array}{l}\text { Size group } \\
\quad(\mathrm{cm} .) \\
6-7\end{array}$} & & & & & \multirow{2}{*}{ Januar } \\
\hline & June & July & August & October & \\
\hline & 0.0 & 0.0 & 0.4 & 0.0 & 0.0 \\
\hline $7-8$ & 0.7 & 0.2 & 0.0 & 0.0 & 0.0 \\
\hline $8-9$ & 0.7 & 0.6 & 0.4 & 0.5 & 0.0 \\
\hline $9-10$ & 0.7 & $I \cdot 3$ & $2 \cdot 8$ & 0.5 & 0.0 \\
\hline IO-II & $2 \cdot 9$ & $3 \cdot I$ & $6 \cdot 0$ & $2 \cdot 0$ & $2 \cdot 6$ \\
\hline II -12 & $5 \cdot 8$ & $3 \cdot 2$ & $5 \cdot 2$ & $\mathrm{I} \cdot 5$ & $7 \cdot 7$ \\
\hline $12-13$ & 9.5 & $3 \cdot I$ & 6.4 & $\mathrm{I} \cdot 5$ & 0.0 \\
\hline $\mathrm{I}_{3}-\mathrm{I} 4$ & II 7 & $7 \cdot 8$ & $9 \cdot 2$ & 0.0 & 0.0 \\
\hline $14-15$ & I3.I & $6 \cdot 7$ & 12.4 & $7 \cdot 0$ & $2 \cdot 6$ \\
\hline $15-16$ & $5 \cdot I$ & 14.5 & 10.8 & 5.5 & $2 \cdot 6$ \\
\hline $16-17$ & $8 \cdot 8$ & 17.0 & 13.6 & $17 \cdot 6$ & $7 \cdot 7$ \\
\hline I7-18 & $17 \cdot 5$ & 15.4 & 9.6 & I6. I & 0.0 \\
\hline $18-19$ & I3.I & II $\cdot 4$ & $9 \cdot 6$ & $17 \cdot 6$ & 20.5 \\
\hline I9-20 & 5.8 & 7.8 & $12 \cdot 0$ & 17.6 & 20.5 \\
\hline $20-2 I$ & $2 \cdot 2$ & 4.4 & $I \cdot 2$ & $9 \cdot 6$ & $25 \cdot 6$ \\
\hline $2 I-22$ & $I \cdot 5$ & $I \cdot 3$ & 0.0 & $2 \cdot 0$ & 10.3 \\
\hline $22-23$ & 0.0 & 0.2 & 0.0 & $\mathrm{I} \cdot \mathrm{O}$ & 0.0 \\
\hline $23-24$ & 0.7 & 0.2 & 0.4 & 0.0 & 0.0 \\
\hline
\end{tabular}

There is no separation into distinct year-classes, but unlike Poulsen's data there is an indication of an increase in the proportion of the larger size-groups throughout the season. The reason for this difference is not entirely clear. Both Poulsen's and Storrow's data were obtained from material obtained over a wide area, or from market catches, while the present catches were always taken in the same place. The simplest explanation would be to assume that differential changes took place (as a result of migrations) with respect to size-groups in the present collections which were taken in one locality, and that this resulted in an accumulation of the larger size-groups in the area sampled.

In these and all other records the great proportion of males in all the catches and at all times of the year has been stressed. Poulsen has suggested that this 
is due to the females burrowing more deeply, and therefore being less likely to be taken in a trawl. The explanation seems hardly adequate; although the smaller animals may, as is suggested later (p. 377) lead a more secluded life, and may therefore be inadequately represented in the catches; an examination

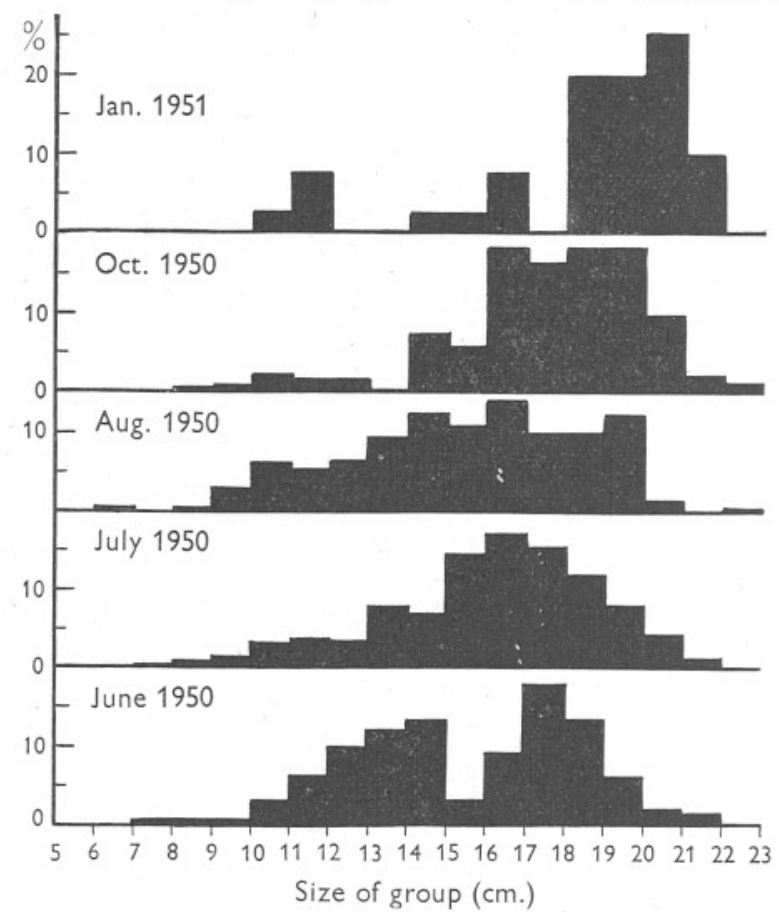

Fig. 2. Size-frequency histograms of Nephrops (collections I-V).

Table V. Size-Frequency (nos.) of Male and Female NEPHROPS FOR 7-I5 CM. GROUPS

\begin{tabular}{crr}
$\begin{array}{c}\text { Size group } \\
\text { (cm.) }\end{array}$ & \multicolumn{2}{c}{ June } \\
\cline { 2 - 3 } $7-8$ & 0 & 0 \\
$8-9$ & I & 0 \\
$9-10$ & I & I \\
IO-II & 3 & 0 \\
II-I2 & 4 & 5 \\
I2-I3 & I4 & I \\
I3-I4 & I4 & 3 \\
I4-I5 & I4 & I
\end{tabular}

\begin{tabular}{|c|c|}
\hline \multicolumn{2}{|c|}{ July } \\
\hline \multicolumn{2}{|c|}{$\hat{0}$} \\
\hline \multicolumn{2}{|c|}{ o } \\
\hline I & I \\
\hline & 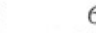 \\
\hline \multirow{2}{*}{$\begin{array}{r}5 \\
\text { II } \\
\text { I } 8\end{array}$} & I \\
\hline & I8 \\
\hline \multirow{3}{*}{$\begin{array}{l}15 \\
25 \\
40\end{array}$} & I I \\
\hline & 2 \\
\hline & 0 \\
\hline
\end{tabular}

\begin{tabular}{|c|c|}
\hline \multicolumn{2}{|c|}{ August } \\
\hline$\hat{\sigma}$ & $c$ \\
\hline I & I \\
\hline 0 & 4 \\
\hline 5 & 5 \\
\hline 9 & 9 \\
\hline 12 & 8 \\
\hline I 2 & 3 \\
\hline 7 & I \\
\hline 9 & I \\
\hline
\end{tabular}

\begin{tabular}{|c|c|}
\hline \multicolumn{2}{|c|}{ October } \\
\hline$\vec{\sigma}$ & $q$ \\
\hline 0 & 0 \\
\hline 0 & $c$ \\
\hline 0 & 0 \\
\hline I & 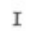 \\
\hline I & 2 \\
\hline 0 & I \\
\hline 3 & I \\
\hline 0 & \\
\hline
\end{tabular}

of the numbers for the smaller size-groups shows that the males and females are caught in roughly equal numbers (Table $\mathrm{V}$ ): this is also seen in the figures given by Poulsen (1946), Storrow (I9I2, I9I3) and McIntosh (1904). The inequality in the sex ratio only becomes apparent when the large size-groups are considered. 
The above facts, together with the smaller size-range of the females, suggests that the sexes are present in the same number up to $\mathrm{I} 2 \mathrm{~cm}$., but beyond this size there is differential mortality-the females living little longer than the time required to reach sexual maturity, while the males continue to grow for some years (contrast Punnett, 1904).

\section{The Habitat of Nephrops and the Barnacle Settlement}

Poulsen remarks that it is well known that adult Nephrops hide in the bottom mud and that this has not been demonstrated for the younger individuals. It has now been shown that these young individuals do indeed burrow in the mud. Fig. 3 is a photograph of a burrow of a $5 \mathrm{~cm}$. Nephrops kept on mud in a tank; the burrow was IO-I $2 \mathrm{~cm}$. in length, shallow and open at both ends, and

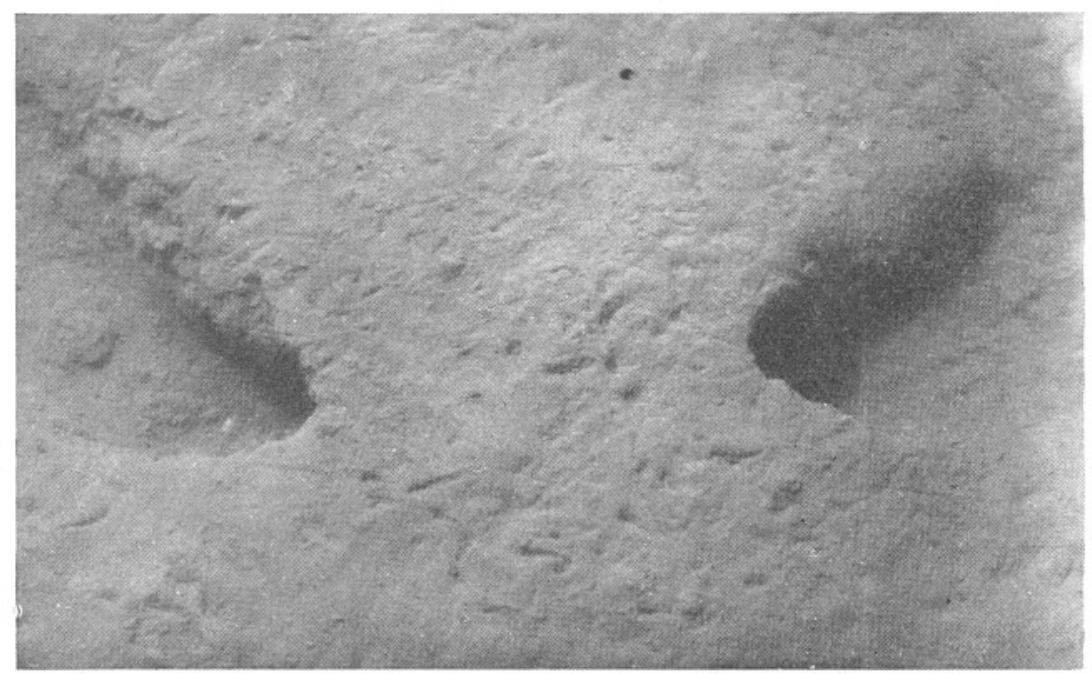

Fig. 3. Burrow made by a $5 \mathrm{~cm}$. Nephrops kept on mud in an aquarium tank. Length of burrow IO-I2 cm., with entrance on the left and the Nephrops completely hidden. $\times 0.7$.

sufficiently long to hide the entire animal (including chelipeds) which indeed had retracted into the burrow before the photograph was taken. Although larger Nephrops have not been seen to make burrows in laboratory experiments it seems unlikely that a burrow proportional in length could readily be maintained in soft mud: this would require a burrow $60 \mathrm{~cm}$. long for a $24 \mathrm{~cm}$. Nephrops.

The above observations suggest that the smaller animals, males and females, may lead a more secluded life than the larger ones and this is borne out by the fact that all the Nephrops up to I I cm. were completely free from barnacles, although it must be remembered that the larger individuals present a larger surface area for settlement. 
The distribution of barnacles on these larger Nephrops is illustrated in Table VI and Fig. 4, and these results suggest quite clearly that the animals spend much of their time in their relatively smaller burrows, with the thorax just protruding and the heavy chelipeds resting with their lower surfaces on the mud.

\section{Table Vi. Distribution of Barnacles (all Sizes), July Collection}

$\begin{array}{lcc}\begin{array}{c}\text { Nephrops } \\ \text { with } \\ \text { barnacles } \\ (\%)\end{array} & \begin{array}{c}\text { Total } \\ \text { barnacles } \\ \text { present } \\ (\%)\end{array} \\ \text { Cephalothorax } & \mathrm{I} 2 & 3.5 \\ \text { Meropodite } & 5 & \mathrm{I} \cdot 2 \\ \text { Carpopodite } & 4 \mathrm{I} & \mathrm{I} 8 \cdot 4 \\ \text { Pro- + dactylopodite } & 74 & 76 \cdot 6 \\ \text { Telson } & \mathrm{I} & 0 . \mathrm{I} \\ \text { Abdomen } & - & 0.3\end{array}$

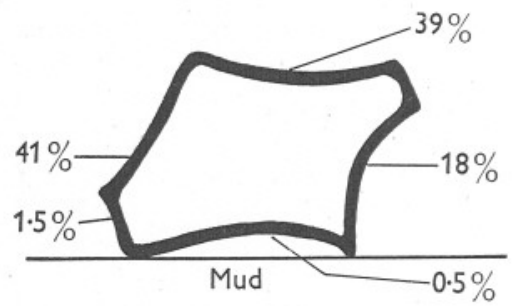

Fig. 4. Diagrammatic cross-section of the right propodite of Nephrops, showing the percentage distribution of barnacles on the various regions for the July collection.

\section{SUMMARY}

Data have been given concerning the size-frequencies, sex and presence of females in berry of Nephrops norvegicus in the Clyde Sea Area, and also the numbers, size and distribution of Balanus crenatus epizoic on the prawns. This entailed the examination of $c$. I200 Nephrops and $c .8000$ barnacles, taken in June, July, August and October 1950 and January I95I.

Four barnacle populations were found during the sampling period, and these have been shown to originate from two periods of settlement (April and August).

The growth-rates of the spring barnacle spat-fall during its first summer, and the settlement of the previous autumn in its second year, are both shown to be about $2 \mathrm{~mm}$. in 4 months, and reasons for, and consequences of, this slow growth-rate are put forward.

It is suggested from the evidence provided by the examination of epizoic barnacles on the prawns that the moulting of the latter takes place irrespective of the size-group, at least annually and largely between late spring and early autumn. 
Females may attain sexual maturity (as evidenced by the carrying of eggs) at $7.5 \mathrm{~cm}$., but the $10 \mathrm{~cm}$. size-group is more commonly mature. Berried females are observed between August and January.

Size-frequency histograms are given for the males, and the shift in the population towards the higher size-groups is tentatively explained on the basis of differential migration.

It is pointed out that the differences in proportion of males and females is only evident when the higher size-groups are included; below $12 \mathrm{~cm}$. the numbers for both sexes are similar for these and other observations. The suggestion that the females burrow more deeply is therefore open to question.

It is shown by laboratory experiments that young Nephrops are able to construct burrows $2 \frac{1}{2}$ times their length; the entire absence of barnacles on prawns of less than II cm. is correlated with the ability of these smaller animals to become completely hidden. The distribution of Balanus crenatus on the larger Nephrops suggests that these also live in the mud but that the burrows are not proportionately as large; they spend much of their time at the entrance of their relatively smaller burrows with the heavy chelipeds resting on the mud surface.

\section{REFERENCES}

BARnes, H. \& BAGENAL, T. B., I95I. A statistical study of the variability in catch obtained by short repeated trawls taken over an inshore ground. Fourn. Mar. Biol. Assoc., Vol. 29, pp. 649-60.

Crisp, D. C., I95I. The habitat of Balanus amphitrite var. denticulata in Britain. Nature. (In the press.)

Foxon, G. E. H., I940. Notes on the life history of Sacculina carcini Thompson. fourn. Mar. Biol. Assoc., Vol. 24, pp. 253-64.

Havinga, B., I929. Krebse und Weichtiere. Handb. Seefisch. Nordeuropas. Bd. 3, pp. I-I47.

Heldt, H. \& Heldt, H., I93r. Des langoustines (Nephrops norvegicus Leach) dans les mers Tunisiennes. Stat. Ocean. de Salammbô, Vol. I6, pp. I-I6.

HöGLund, H., I942. De matnyttige kräftdjuren. Fisker och Fiske $i$ Norden. Stockholm, 1942.

McINTOSH, D. C., I904. On variation in number and arrangement of the male genital aperture and on the proportion of the sexes in the Norway lobster (Nephrops norvegicus). Proc. Camb. Phil. Soc., Vol. I2, pp. 44I-4.

- 1908. Variation in the Norway Lobster. (Nephrops norvegicus). Proc. Roy. Phys. Soc., Vol. 17, pp. I29-42.

Meek, A., I903. The migration of crabs. Northumberland Sea Fish. Comm. Rept. Sci. Investig., 1903, pp. 33-5.

- I913. Migration of crabs. Dove Mar. Lab. Rept., I9I2-13, pp. 13-20.

- I9I4. Migration of the crab. Dove Mar. Lab. Rept., 1913-14, pp. 73-6.

Poulsen, E. M., I946. Investigations on the Danish fishery for and the biology of the Norway lobster and deep sea prawn. Rept. Danish Biol. Stat., Vol. 48, pp. 27-49. 
Punnett, R. C., I904. Note on the proportion of sexes in Carcinus maenas. Proc. Camb. Phil. Soc., Vol. I2, pp. 293-6.

Pyefinch, K. A., 1948. Notes on the biology of Cirripedes. Fourn. Mar. Biol. Assoc., Vol. 27, pp. 464-503.

Storkow, B., I9I2. The prawn (Norway lobster, Nephrops norvegicus) and the prawn fishery of North Shields. Dove Mar. Lab. Rept., I9I I-12, pp. I0-3I.

- I9I3. The prawn (Norway lobster, Nephrops norvegicus) and the prawn fishery of North Shields. Dove. Mar. Lab. Rept. 1912-13, pp. 9-12.

Topsent, E., I9ri. Croissance et mort des balanes à Luc-sur-Mer. Ann. Inst. Océanogr., T. 2, Fasc. 6, 3 pp."

Zariquiey-CenarRo, R., I935. Crustaceás del Mediterranéo (Decapodos Macruros) Nephrops norvegicus L. var. meridionalis. Bull. Inst. Catalana Hist. Nat., Vol. 35, pp. 26-32. 